Ritstýrð grein birt 31. desember 2020

\title{
Frásagnir barna á tímum COVID-19
}

\author{
Salvör Nordal, Sigurveig Pórhallsdóttir og Eðvald Einar Stefánsson \\ Abstract \\ - Um höfunda \\ About the authors \\ Heimildir
}

Í pessari grein er fjallað um frásagnir barna og ungmenna um hvernig pað er að vera barn á tímum kórónuveirunnar og hvernig faraldurinn hafði áhrif á líf peirra vorið 2020. Efninu er skipt upp í fimm flokka; fyrst er fjallað almennt um líf barna á pessum tíma, hinir fjórir flokkarnir endurspegla pau málefni sem helst brunnu á börnunum, en pau voru skólinn, tómstundir, fjölskyldan og vinir og loks sóttvarnaaðgerðir. Miklar breytingar urðu á skólahaldi og tómstundastarfi, sérstaklega frá 16. mars til 4. maí pegar umfangsmiklar samkomutakmarkanir voru í gildi. Samverustundir fjölskyldunnar urðu almennt fleiri á pessu tímabili par sem börn og foreldrar voru meira heima en vanalega.

Umboðsmaður barna leggur í starfi sínu áherslu á 12. gr. Barnasáttmálans sem kveður á um rétt barna til pess að taka pátt í samfélagslegri umræðu og að tekið sé tillit til sjónarmiða peirra. Мeð pað að markmiði að fá upplýsingar um hvernig börn upplifðu pennan tíma sendi umboðsmaður barna bréf til allra grunnskóla í byrjun mars par sem óskað var eftir frásögnum barna og ungmenna um hvernig pað er að vera barn á tímum kórónuveirunnar og hvernig faraldurinn hafði áhrif á daglegt líf peirra. Verkefnið var jafnframt kynnt á samfélagsmiðlum. Skilafrestur var til enda skólaársins vorið 2020. Alls bárust 116 svör frá börnum og ungmennum, mest var af skriflegum frásögnum en einnig bárust myndir, ljóð og myndskeið. Samantekt af frásögnum barnanna var birt á vefsíðu umboðsmanns í október 2020 og var einnig kynnt í fréttum á KrakkaRÚV. Með pví að fá fram sjónarmið barna má betur draga lærdóm af reynslu peirra og hvernig haga beri takmörkunum sem pessum í framtíðinni eða pegar aftur parf að grípa til svo afdrifaríkra inngripa í samfélagið.

Efnisorð: Umboðsmaður barna, kórónuveiran, COVID-19, frásagnir barna, réttindi barna, Barnasáttmálinn, grunnskóli, nemendur, ípróttir og tómstundir, samkomubann, fjölskyldan

\section{Inngangur}

Umboðsmaður barna óskaði eftir frásögnum barna og ungmenna um hvernig pað væri að vera barn á tímum kórónuveirunnar og hvernig faraldurinn hefði haft áhrif á daglegt líf peirra vorið 2020. Í pessari grein er fjallað um svör barnanna en ljóst er að pau hafa fylgst vel með fréttum af kórónuveirunni og hugleitt sjúkdóminn og afleiðingar hans mikið. Í greininni er efninu skipt upp í fimm flokka; fyrst er fjallað almennt um líf barna á pessum tíma, hinir fjórir flokkarnir endurspegla pau málefni sem helst brunnu á börnunum, en pau voru skólinn, tómstundir, fjölskylda og vinir og loks sóttvarnaaðgerðir.

Kórónuveirufaraldurinn (COVID-19) hefur haft víðtækar afleiðingar fyrir samfélagið, ekki síst börn og fjölskyldur peirra. Samkomutakmarkanir tóku gildi 16. mars árið 2020 og var skólahald takmarkað fram til 4. maí pað sama ár. Á pessum tíma fór framhaldsskólakennsla fram með fjarkennslu og 
í grunnskólum máttu ekki fleiri en 20 nemendur vera í sömu kennslustofu. Í leikskólum purfti að leitast við að hafa börn í eins litlum hópum og mögulegt var. Vegna pessara ráðstafana urðu töluverðar breytingar á kennsluaðferðum og námsmati í skólum landsins en hverjum og einum skóla var falið að útfæra kennslu og námsmat. Sumir skólar gátu boðið upp á staðkennslu fyrir nemendur hluta úr degi en aðrir skólar höfðu alla kennslu á netinu.

Breytt skólastarf hafði veruleg áhrif á félagslíf barnanna innan skólans og utan. Grunnskólar og leikskólar skiptu margir hverjir börnum upp í nokkra hópa par sem hver hópur umgekkst eingöngu börn úr sínum hópi í skólanum. Jafnframt var mælst til pess að skólafélagar sem voru ekki í sama hópi í skólanum væru ekki að umgangast utan skóla. Samkomutakmarkanir höfðu ekki aðeins áhrif á skólastarf. Skipulagt ípróttastarf og margvíslegt annað tómstundastarf féll niður eða færðist yfir í fjarkennslu. Pá höfðu samkomutakmarkanir mikil áhrif á fjölskyldulíf barna par sem samvera fjölskyldunnar jókst almennt til muna, m.a. vegna pess að börn voru styttri tíma í skólanum og margir foreldrar unnu heima.

\section{Hvers vegna frásagnir barna?}

Umboðsmaður barna leggur í starfi sínu áherslu á 12. gr. Barnasáttmálans sem kveður á um rétt barna til pess að taka pátt í samfélagslegri umræðu og að tekið sé tillit til sjónarmiða peirra (lög nr. 18/1992 um samning Sameinuðu pjóðanna um réttindi barnsins). Börn búa yfir einstakri pekkingu og geta ein sagt til um hvernig pau upplifa aðstæður sínar. Af pessum ástæðum er brýnt að leita sjónarmiða barna um sem flest málefni samtímans en til pess eru fjölmargar leiðir mögulegar. Nokkrir fræðimenn hafa próað kenningar um pátttöku barna í ákvarðanatöku. Roger Hart var brautryðjandi á pessu sviði. Hart setti fram átta prepa pátttökustiga par sem nánast engin pátttaka er í neðsta prepinu en hún eykst eftir pví sem farið er ofar í stigann (Hart, 1992, 2008). Aðrir sem hafa látið til sín taka á pessu sviði eru pau dr. Laura Lundy (2007) og Harry Shier (2001). Lundy er einn helsti sérfræðingur samtímans í samfélagslegri pátttöku barna. Greining Lundy á pátttöku barna grundvallast á 12. grein Barnasáttmálans og peim forsendum sem purfa að vera til staðar svo að börn geti raunverulega látið skoðanir sínar í ljós og haft áhrif. Pessar forsendur eru fjórar; pær eru rödd, áheyrn, vettvangur og áhrif. Margir hafa nýtt sér greiningu Lundy við pátttöku barna og má par m.a. nefna að pað var gert við skipulag barnapings árið 2019 (Umboðsmaður barna, 2019).

Umboðsmaður barna hefur lagt áherslu á að samráð sé haft við börn pegar teknar eru ákvarðanir um breytingar á skólastarfi. Samkomutakmarkanir áttu sér ekki langan aðdraganda og purftu skólar að bregðast hratt við til að aðlaga skólastarfið kröfum um sóttvarnir. Par unnu kennarar og skólastjórnendur prekvirki enda raskaðist kennsla hér á landi mun minna en í nágrannalöndunum. Prátt fyrir skamman tíma er ávallt mikilvægt að reyna eins og kostur er að hafa samráð við nemendur um breytingar.

Umboðsmanni barna bárust fyrirspurnir frá börnum vegna peirrar röskunar sem varð á skólastarfi í kjölfar peirra aðgerða sem gripið var til í peim tilgangi að hefta útbreiðslu kórónuveirunnar. Börn og ungmenni vildu m.a. vita hvort yfirstandandi önn í grunn- og framhaldsskólum yrði lengd, hvernig staðið yrði að einkunnagjöf í skólum og inntöku nemenda í framhaldsskóla. Umboðsmaður vakti athygli mennta- og menningarmálaráðherra á pessu með bréfi sem sent var pann 15. apríl. Kom par fram að óvissa um framgang skólastarfs ylli börnum mikilli streitu og áhyggjum. Ljóst væri að skólar og skólayfirvöld pyrftu að grípa til ýmissa ráðstafana til pess að tryggja rétt barna til menntunar og brýnt væri að nemendur í skólum væru pátttakendur í peirri ákvarðanatöku, fengju nauðsynlegar upplýsingar um pá valkosti sem væru mögulegir, og fengju að koma sínum sjónarmiðum á framfæri, áður en endanleg ákvörðun yrði tekin. Umboðsmaður barna lagði jafnframt áherslu á að mennta- og menningarmálaráðherra myndi beina peim tilmælum til stjórnenda skóla, að við töku ákvarðana um tilhögun skólastarfs yrði hugað sérstaklega að rétti barna til upplýsinga og pátttöku samkvæmt ákvæðum Barnasáttmálans (Umboðsmaður barna, 2020).

Samkomutakmarkanir pær sem beitt var hér á landi höfðu mikil áhrif á daglegt líf barna. Pví er 
mikilvægt að finna leiðir til að fá upplýsingar um hvernig börnin upplifðu pennan tíma og veita peim tækifæri til að tjá pað á frjálsan og ópvingaðan hátt. Með pví að fá fram sjónarmið barna má betur draga lærdóm af reynslu peirra og hvernig haga beri takmörkunum sem pessum í framtíðinni eða pegar aftur parf að grípa til svo afdrifaríkra inngripa í samfélagið.

\section{Аðferðafræði}

Umboðsmaður barna sendi öllum grunnskólum bréf í byrjun mars par sem óskað var eftir frásögnum barna og ungmenna um hvernig pað væri að vera barn á tímum kórónuveirunnar og hvernig faraldurinn hefði haft áhrif á daglegt líf peirra. Jafnframt var verkefnið kynnt á samfélagsmiðlum. Verkefnið var unnið í samvinnu við KrakkaRÚV. Ekki voru gerðar sérstakar kröfur um form frásagna heldur voru börn hvött til pess að senda myndir, skriflegar færslur eða myndskeið. Skilafrestur til að senda inn efni var til loka skólaársins vorið 2020.

Alls bárust 116 svör frá börnum og skólum víðs vegar að af landinu. Aldur barnanna var breiður, allt frá fyrstu bekkjum grunnskóla til efstu bekkinga. Mest barst af skriflegum frásögnum en einnig voru sendar inn myndir, dagbókarfærslur og ljóð. Pá var nokkuð sent af myndskeiðum með frásögnum, viðtölum og leiknu efni. Líklegt er að beiðnin um frásagnir hafi ekki náð til allra hópa barna í samfélaginu og eru svörin að einhverju leyti háð áhuga tiltekinna skóla eða kennara. Hér er pví ekki um pversnið að ræða eða úrtaksrannsókn. Eftir sem áður pá bregða frásagnirnar upp mikilvægri mynd af hugarheimi barna á pessum tíma.

Umboðsmaður barna hefur áður kallað eftir frásögnum barna en pað var gert veturinn 2008 til 2009 í kjölfar fjármálakreppunnar. Niðurstaða pess verkefnis var birt í ritinu Hvernig er að vera barn á Íslandi? (Umboðsmaður barna, 2009).

Í október 2020 voru samantektir og tilvitnanir í frásagnir barna af kórónuveirunni birtar á vefsî̉u umboðsmanns barna, barn.is, pá var einnig fjallað um pær í fréttum á KrakkaRÚV auk pess sem sýnt var myndband með nokkrum frásögnum.

\section{Almennt um lífið á tímum kórónuveirunnar}

Af svörum barnanna má merkja að kórónuveiran hafi haft umfangsmikil áhrif á daglegt líf barna. Mörgum fannst lífið vera skrýtið og sumir upplifðu að heimurinn væri öðruvísi. Algengt var að börnin tækju fram að peim hefði liðið vel á pessum tíma. Рað hefði verið minna stress á morgnana og pau hefðu náð betri svefni. Fólk hefði haft meiri tíma en áður m.a. til pess að hreyfa sig, elda og vera með fjölskyldunni. Talsverð áhersla var lögð á mikilvægi pess að eiga góða fjölskyldu og vini.

Börnin ræddu ekki aðeins neikvæð áhrif kórónuveirunnar heldur sáu mörg peirra jákvæðar hliðar á peim breytingum sem höfðu orðið vegna hennar. Samverustundir fjölskyldunnar væru fleiri og pá hefðu pau lært mikið á pessum tíma, t.d. hvað vinátta skiptir miklu máli, hvað pað er mikilvægt að gera gott úr hlutunum, hugsa jákvætt og finna sér eitthvað að gera. Pó almennt hafi komið fram að börnunum hafi liðið vel voru einnig börn sem greindu frá að peim hefði liðið illa, pau hefðu átt erfitt með allar pær breytingar sem orðið höfðu á samfélaginu og óttuðust að nákomnir ættingjar myndu smitast. Pau voru meðvituð um að margir hefðu smitast af veirunni, einnig að ástandið væri sérstaklega erfitt í ákveðnum löndum og að margir hefðu dáið vegna kórónuveirunnar í heiminum. Fram kom að pað hefði verið leiðinlegt fyrir pá sem áttu afmæli á pessum tíma að geta ekki haldið veislu. Í mörgum frásögnum var fjallað um atvinnu foreldra og pær breytingar sem höfðu orðiðá vinnu peirra, sumir væru að vinna heima, aðrir mættu í vinnuna eða væru að leita sér að vinnu.

Mér leið mjög vel á tímum COVID enda er ég mjög heppin með fjölskyldu. Ég náði að einbeita mér betur að náminu og fékk að sofa lengur. Engin sem ég pekki hefur veikst pannig ég er búin að vera einstaklega heppin á pessum erfiðu og skrítnu tímum og er 
pakklát fyrir pað.

Mamma mín hún vinnur minna og við eigum ekki jafn mikla peninga og áður en við eigum nóg fyrir húsinu og mat en ekki nýju dóti sem við purfum ekki. Êg er mjög glöð að við eigum ennpá eitthvað.

Mér er búið að líða ópægilega og skringilega. Petta er stressandi en samt líka spennandi. Petta er sorglegt út af peim sem eru að deyja. Pirrandi og leiðinlegt að geta ekki farið í skólann eða leikið við vini mína. Á sama tíma er petta pínu skemmtilegt. Ef ég ætti að lýsa pessu í einu orði væri pað SKRÍTIĐ! Mér líður alls konar.

Mér leið sérstaklega vel í samkomubanninu vegna pess að pað var ekkert stress á morgnana, maður fékk að taka pví rólega og allt var mjög rólegt og pægilegt par sem maður gat verið enn pá í náttfötum fram eftir degi sem var mjög notalegt.

\section{Skólinn}

Í mörgum frásögnum var fjallað um pær breytingar sem gerðar voru á skólahaldi. Fram kom að skólatími væri mun styttri en vanalega en heimanámið hefði hins vegar aukist til muna. Börnunum fannst skrítið að purfa að sitja ein og að fá ekki að fara í frístund. Mörgum leið eins og pau væru í sumarfríi, pað hefði verið notalegt að geta sofið lengur á morgnana og vera í náttfötunum að læra. Í nokkrum frásögnum kom fram að börn hefðu náð að sofa meira en vanalega. Skiptar skoðanir komu fram um fjarkennslu og fannst mörgum erfitt að læra heima á meðan aðrir voru ánægðir með hvernig hefði tekist til og tóku fram að verkefnin hefðu verið fjölbreytt. Sumum fannst pægilegt að vinna heima á meðan aðrir áttu erfitt með pað. Nokkur börn tóku fram að pau hefðu ekki getað fengið hjálp við heimanámið, m.a. par sem foreldrar peirra hefðu verið mikið á fundum. Pá hefði einnig verið erfitt að læra heima út af öllum peim truflunum sem par væru, bæði hefðu verið læti og einnig hefði verið erfitt að hafa Internetið, YouTube og tölvuleiki við hendina og að kennarinn hefði ekki getað fylgst með hvað nemendur væru að gera. Fram kom að pað hefði verið erfitt fyrir suma kennara að viðhafa fjarkennslu ef peir höfðu takmarkaða tæknipekkingu. Pá söknuðu börnin pess að geta ekki lært með vinum sínum. Mörg börn nefndu að pau hefðu purft að spritta hendur í hvert skipti sem pau komu inn í skólastofuna. Í flestum skólum var nemendum skipt upp í hópa og var reynt að koma í veg fyrir samskipti par á milli. Petta fannst mörgum börnum erfitt, sérstaklega ef bestu vinir peirra voru í öðrum hóp en pau sjálf. Mörg barnanna hlökkuðu til pess að skólinn yrði aftur með hefðbundnu sniði pann 4. maí. Sumum fannst að verið væri að brjóta gegn réttindum barna með pví að hefja ekki venjulegt skólahald fyrr en 4. maí, höfðu áhyggjur af peim sem pyrftu á aðstoð að halda í náminu og einnig peim sem ættu erfitt með breytingar, t.d. börnum sem eru einhverf.

Einn af erfiðustu pörtunum við að læra heima eru allar truflanir sem koma og ekki bara læti og pannig en líka sumir hlutir eins og að hafa internetið og YouTube eða tölvuleiki bara parna og engin leið fyrir kennarann að vita hvað pú varst að gera.

Sumir kennarar áttu erfitt með að kenna í gegnum tölvur og kunnu bara ekkert á tölvur. En eftir nokkrar vikur pá lærðu pau að nota pær og allir kennararnir.

Bara að hugsa sér alla sem purfa aðstoð í náminu sem fá ekki almennilega hjálp út af pessu. Alla sem höndla breytingu MJÖG illa, m.a. einhverf börn.

Skólinn breyttist og var bara á priðjudögum og fimmtudögum í 2 klukkutíma en samt fullt af heimanámi. 


\section{Fjölskylda og vinir}

Í frásögnum barnanna var áberandi að pau söknuðu pess að geta leikið við alla vini sína eins og venjulega. Pá fannst mörgum erfiðast við kórónuveiruna að geta ekki umgengist alla vini sína. Pað hefði hjálpað að geta átt samskipti í gegnum FaceTime en pað kæmi ekki í stað pess að hittast augliti til auglitis og pað væri leiðinlegt að geta ekki faðmast. Pau börn sem gátu hitt vini sína voru ánægð með pað, pau hefðu bakað, spilað, farið í göngutúr eða út að hjóla saman. Algengt var að börnin tækju fram að samverustundir fjölskyldunnar hefðu verið fleiri sem væri jákvætt og pau hefðu orðið nánari foreldrum sínum. Pá tóku nokkur börn fram að pau væru pakklát fyrir að eiga góða fjölskyldu. Pað hefði samt verið skrítið að vera svona mikið heima með foreldrum sínum. Pá kom fram að foreldrar hefðu verið óvenju mikið á fundum en aðrir foreldrar unnið minna en vanalega. Fram kom að börnin hefðu fengið að aðstoða við heimilisverkin eins og að prífa og búa til mat, á sumum heimilum var ráðist í framkvæmdir og fengu börnin að aðstoða við pær. Pau sem áttu systkini voru pakklát fyrir að hafa einhvern að leika sér við heima. Mörgum fannst erfitt að geta ekki heimsótt afa sinn og ömmu og hlökkuðu til að mega knúsa pau. Heimilisaðstæður barna eru fjölbreyttar og petta tímabil gat verið flókið fyrir pau börn sem eiga tvö heimili.

Ég fékk ekki að hitta ömmu og afa sem ég hitti venjulega á hverjum einasta degi. Ég saknaði peirra rosalega mikið.

Ég mátti ekki hitta tvær bestu vinkonur mínar sem ég hitti venjulega á hverjum einasta degi. En sem betur fer á ég prjár bestu vinkonur og ein peirra er í mínum hóp.

Mamma vildi fyrst pegar pað var sett samkomubann að við myndum ekki fara til pabba [...] En svo varð petta lengra og lengra og við söknuðum pabba og pabbi saknaði okkar pannig að pá leyfði mamma okkur að fara til pabba.

Pegar petta samkomubann byrjaði mamma og pabbi að rífa upp pvottahúsið og setja innréttingar og gera pað flottara. Pau eru ekki enn búin með pað en pegar pau eru búin pá verður petta mjög flott.

\section{Tómstundir, ípróttir og tónlistarnám}

Ípróttaæfingar lágu að mestu niðri á peim tíma sem samkomubann stóð yfir og nefndu mörg börn að ípróttirnar hefðu tekið hvað mestum breytingum. Pau börn sem æfa fótbolta voru almennt ánægð með að boðið hefði verið upp á heimaæfingar. Æffingarnar hefðu verið fjölbreyttar, bæði tækniæfingar og prek- og styrktaræfingar. Sum börn fóru oftar út í göngutúr eða út að hlaupa. Pá fannst sumum petta kærkomin hvíld par sem vanalega gæfist ekki tími fyrir annað en að mæta í skólann og á æfingar. Önnur töluðu um að pau hefðu misst polið og stundum liðið illa. Fram kom að pað hefði verið andlega erfitt að komast ekki á æfingar og að hreyfa sig lítið, peim hefði liðið mun betur pegar pau fóru reglulega á æfingar. Sum fundu fyrir andleysi og fengu sig ekki til pess að hreyfa sig. Pau börn sem gátu farið á hestbak fannst pað mikilvægt og skemmtilegt. Fram kom að fótboltaæfingar hefðu hafist á sama tíma og skólinn en pá hefði purft að spritta og pvo hendur fyrir og eftir æfingu. Fram kom að fjölbreytt kennsla hefði farið fram í gegnum fjarfundabúnað og má par nefna tónlistarnám og skákkennslu. Mörgum fannst mjög leiðinlegt að geta ekki farið í sund og pá hefðu allar gönguleiðir verið fjölfarnar af fólki sem ekki gat farið í líkamsræktarstöðvar pví pær voru lokaðar. Talsvert var um að börn hefðu verið mikið inni og notað tímann til pess að spila tölvuleiki.

Ég gerði líka mikið af heimaæfingum í fótboltanum og ég er búin að bæta metið mitt að halda á lofti um 42 síðan kórónuveiran byrjaði.

Ég bara fæe ekki motivationið fyrir pví að koma mér í gang og byrja að hreyfa mig. Vanalega er ég á æfingum 3-4 sinnum í viku og ég finn bara að mér líður mikið betur pá. 
Fótboltinn fyrir mig breyttist lang mest. Pegar maður vaknaði pá var heimaæfing á komin (í fótbolta). Allar æfingarnar voru alltaf með einhverjar tækniæfingar eða halda á lofti. Síðan voru á öðrum hverjum degi pol eins og hlaup eða sprettir. Í endann var oftast einhver heimastyrkur eins og bak og magaæfingar eða armbeygjur. Ég sjálfur gerði allar æfingarnar, sleppti einu poli en gerði yfirleitt aukalega.

Par sem ég æfi skák fór hún bara fram í gegnum netið. Ég hitti kennarana í forriti sem heitir Zoom og svo notuðum við vefsíðu sem heitir Chess.com. Netskákmótum fjölgaði til muna og meira að segja landsmótið í skák er á netinu.

\section{Sóttvarnaaðgerðir}

Mikið var fjallað um hreinlæti og sérstaklega hve oft pyrfti að spritta hendur. Einnig var talsvert fjallað um tveggja metra regluna og hvernig hún hefði virkað, í skólum og verslunum. Ekki hefði mátt snerta neitt í verslunum og pá hefðu fjölskyldur takmarkað fjölda ferða í matvöruverslanir. Fólk hefði passað að halda tveggja metra fjarlægð frá næsta manni og að hósta ekki. Flest börn voru augljóslega meðvituð um pær sóttvarnaaðgerðir sem gripið hafði verið til og skildu að pessar aðgerðir ættu að draga úr smithættu. Pá vissu pau einnig að um tímabundið ástand væri að ræða. Einnig kom fram að ákveðnir hópar væru í mikilli áhættu og pá pyrfti að passa sérstaklega vel.

Í mörgum frásögnum var tekið fram að pað hefðu margir dáið vegna kórónuveirunnar í heiminum og að ástandið væri verulega alvarlegt í ákveðnum löndum. Almennt voru börnin ekki hrædd við að fá veiruna sjálf og voru peirrar skoðunar að pað væri líklegra að eldra fólk yrði meira veikt. Pess vegna höfðu mörg börn áhyggjur af afa sínum og ömmu. Nokkur börn sendu inn frásagnir um hvernig pað var að vera í sóttkví. Almennt voru börnin ánægð með viðbrögð íslenskra stjórnvalda og pá samstöðu sem hefði myndast í samfélaginu. Pá voru pau ánægð með heilbrigðiskerfið.

Mörg barnanna pekktu einhvern sem purfti að fara í sóttkví eða hafði smitast og verið í einangrun. Pau höfðu áhyggjur af að einhver nákominn peim myndi smitast og fannst mikilvægt að fjölskyldan passaði sig sérstaklega vel. Fram kom að foreldrar hefðu margir hverjir verið strangir hvað varðaði hreinlæti og að farið væri eftir reglum stjórnvalda, pað hefði verið pirrandi en samt jákvætt. Pá kom einnig fram gagnrýni á pær aðgerðir sem gripið hafði verið til. Sneri sú gagnrýni fyrst og fremst að pví að aðgerðir ættu ekki að taka til barna par sem ólíklegt væri að pau smituðust eða smituðu aðra. Brotið væri gegn réttindum barna með pví að hefja skólahald ekki fyrr en 4. maí. Pá ættu samkomutakmarkanir aðeins að taka til peirra sem væru 17 ára og eldri. Búið væri að hræða foreldra sem hefðu síðan hrætt börn sín. Börn væru farin að segja foreldrum sínum ósatt um hvert pau væru að fara og hverja pau væru að hitta til pess að geta átt samskipti við vini sína. Pau börn sem hlýddu foreldrum sínum ættu á hættu að verða einmana og punglynd.

Petta er búið að vera skrítið, mjög skrítið. En er frekar ánægður hvernig Íslandi er búið að ganga í pessu pví pað er flókið að tækla svona stór vandamál og hvað pjóðin er búin að standa vel saman.

„Petta er ekki pað versta sem hægt er að lenda í og við hér á Íslandi erum svo heppin með heilbrigðiskerfið okkar, svo lengi sem við stöndum saman pá komumst við í gegnum petta og ekki gleyma, hlýðum Víði.

Svo var sett 2 metra reglan [...] HVAĐ ER PAÐ!!!: 2 metra reglan er að pað eiga að vera 2 metrar á milli fólks til að minnka smithættu [...] En hvað er smithætta? Smithætta er að pað er hætta á að maður smitist. 2 metra reglan var sett svo maður væri ekki ofan í öðrum og pannig dregur úr smithættu.

Раð hafa margir dáið. Pað má ekki hitta gamalt fólk út af pví að pað eru meiri líkur að gamalt fólk deyi en fullorðið fólk. Pað eru margir búnir að fá veiruna. Ef maður fær veiruna 
pá parf maður að fara í einangrun, pá má maður ekki hitta neinn og pá parf maður að hanga heima í tvær vikur. Ef maður er búinn að hitta einhvern sem hefur fengið veiruna pá parf maður að fara í sóttkví, pá er maður ekki að hitta fólk. Maður getur bara fengið veiruna 1 sinni.

Krakkar eru farnir að ljúga að foreldrum sínum hvert peir eru að fara til að geta hitt vini sína og haft almennileg mannleg samskipti. Auðvitað er pað skiljanlegt ef einhver er með undirliggjandi sjúkdóm á heimilinu og eru hræddir en annars ætti pað ekki að hafa áhrif á samskipti barna.

\section{Umræður og lokaorð}

Framangreindar frásagnir sýna hversu umfangsmikil áhrif kórónuveiran og sóttvarnaaðgerðir, pá einkum takmarkanir á skólahaldi og tómstundastarfi, höfðu á líf barna. Svör barnanna endurspegla fjölbreytileg sjónarhorn peirra og hversu meðvituð pau eru um samfélag sitt. Athygli vekur hve mörg barnanna ræddu um minna álag á heimilinu og tækifæri til að sofa lengur en venjulega pegar um hægði í samfélaginu. Petta kallast á við rannsóknir sem sýndu að almennt leið íslenskum börnum og ungmennum betur í fjármálakreppunni en árin par á undan (Rannsóknir og greining, e.d.). Jafnframt kemur fram að pau töluðu um aukið heimanám í skólanum með aukinni fjarkennslu. Petta er til umhugsunar í ljósi pess að ítrekað hefur komið fram að börn telji nauðsynlegt að minnka heimanám í skólakerfinu. Minna heimanám var eitt af pví sem börn lögðu hvað mesta áherslu á pegar barnaping var haldið árið 2019 (Umboðsmaður barna, 2019). Velta má fyrir sér hvort ástæðan sé mikið álag í lífi margra barnafjölskyldna eftir venjulegan skóladag sem geri pað að verkum að erfitt sé að finna tíma til að sinna heimanáminu.

Í yfirlýsingu barnaréttarnefndar Sameinuðu pjóðanna frá 8. apríl 2020 er áréttað að aðildarríki Barnasáttmálans eigi að ná fram sjónarmiðum barna og taka tillit til peirra pegar ákvarðanir eru teknar um ráðstafanir er tengjast heimsfaraldrinum. Börn eigi jafnframt að skilja hvað sé að gerast og upplifa að pau eigi aðkomu að peim ákvörðunum sem teknar eru vegna hans (United Nations, 2020). Mikilvægt er að börn fái tækifæri til pess að vera pátttakendur í samfélagslegri umræðu. Samkvæmt 12. gr. Barnasáttmálans ber aðildarríkjum hans að tryggja börnum rétt til að láta skoðanir sínar frjálslega í ljós í öllum málum sem pau varða, og skal tekið réttmætt tillit til skoðana peirra. Jafnframt parf að hvetja börn til að mynda sér skoðanir og búa til aðstæður sem styðja pau við að tjá sig. Pá er mikilvægt að auka virðingu fyrir skoðunum barna og leita markvisst eftir peim.

\section{Children's views in the times of COVID-19}

In the spring of 2020, the Ombudsman for Children in Iceland called for narratives from Icelandic children on being a child in the times of the COVID-19 pandemic and how it has affected their daily lives and routine. Their answers are analysed in this article. The narratives are divided into five categories: discussions on the general effect of the pandemic, as well as four recurring issues in the children's answers; that is school, leisure activities, family and friends and responses to COVID-19. The pandemic has had a profound impact on our society, not least on children and their families.

It is clear from the answers received by the Ombudsman that Icelandic children have paid close attention to news regarding the COVID-19 pandemic and its impact on society. Substantial limitations on people's right to gather were put in place on the 16th of March which extended to schools, with limitations lasting until the 4th of May when schools were able to operate in a conventional manner. The majority of schools had to rely on online teaching to some extent, some more than others. 
Changes within the schools and leisure activities had an instrumental impact on children. They spent more time at home with their families as many of them only attended school in a limited fashion while many parents worked from home. In light of these wide-ranging consequences it is essential to gather information as to how the children experienced these changes in their lives in an attempt to make certain that when parallel measures need to be taken, they reflect the needs of children and are aimed at ensuring their rights.

The Ombudsman for Children has emphasized the importance of Article 12 of the United Nations Convention on the Rights of the Child and children's right to participation. According to Article 12, children's views should be sought, heard, and considered in relation to all matters that concern them. It is important to provide children with the opportunity to be heard and to have their point of view considered when decisions are made concerning measures in relation to the pandemic. A letter was sent to every elementary school in Iceland in the beginning of March where the Ombudsman requested children to send in stories of their daily lives during the COVID-19 pandemic. No requirements were made concerning the construction of the answers; thus, children were encouraged to hand in pictures, written statements, or videos. Children had until the end of the school year in spring 2020 to respond. The Ombudsman received 116 answers from children across the country who handed in written statements, pictures, journals, and poems. There were also a few video clips with stories and plays. Probably the Ombudsman's request did not reach all groups of children and the answers are in some respect dependent on the interest of certain teachers or schools. Nonetheless these narratives provide an important insight into the lives of children during the COVID-19 pandemic. A summary of the children's answers was published in October 2020 on, www.barn.is, which is the webpage of the Ombudsman for Children in Iceland. This summary was also reported on the children's news channel on the KrakkaRÚV where video clips from children were shown.

In their narratives the children emphasized that their lives were different now than before the pandemic and that many things were strange. The children generally expressed feeling content during this time. Among recurring topics was the impact the pandemic had on their families with more time spent together at home. The children reported that there was less tension in their homes in the morning and that they had the opportunity to catch up on sleep. They missed their friends and grandparents and looked forward to being able to see them and hug them like before. The children talked about there being more homework and they were generally pleased with the manner of remote teaching online. They were generally satisfied with the measures taken to diminish the pandemic although some were unhappy with them. These narratives provide an important insight into children's views and their lives during the first outbreak of the COVID-19 pandemic in Iceland.

Key words: Ombudsman for children, Children's views, COVID-19, elementary school, children's rights, lockdown

\section{Um höfunda}

Salvör Nordal er umboðsmaður barna.

Sigurveig Pórhallsdóttir starfar sem lögfræðingur hjá embætti umboðsmanns barna.

Eðvald Einar Stefánsson starfar sem sérfræðingur hjá embætti umboðsmanns barna. 


\section{About the authors}

Salvör Nordal is Ombudsman for Children in Iceland.

Sigurveig Pórhallsdóttir is Legal Advisor at the office of the Ombudsman for children.

Eðvald Einar Stefánsson is Senior Advisor at the office of the Ombudsman for children.

\section{Heimildir}

Hart, R. (1992). Children's participation. From tokenism to citizenship. Innocenti essays no. 4. Sótt af https://www. unicef-irc.org/publications/pdf/childrens_participation.pdf

Hart, R. (2008). Stepping back from 'the ladder': Reflection on a model of participatory work with children. Í A. Reid, B. B. Jensen, J. Nikel og V. Simovska (ritstjórar), Participation and learning (bls. 19-31). New York: Springer.

Lundy, L. (2007). 'Voice' is not enough: Conceptualising Article 12 of the United Nations Convention on the rights of the child. British Educational Research Journal, 33(6), 927-942. Sótt af https://bera-journals. onlinelibrary.wiley.com/doi/abs/10.1080/01411920701657033

Lög nr. 18/1992 um samning Sameinuðu pjóðanna um réttindi barnsins.

Rannsóknir og greining. (e.d.). Skýrslur. Sótt af https://rannsoknir.is/skyrslur/

Shier, H. (2001). Pathways to participation: Openings, opportunities and obligations. Children \& Society, 15(2), 107-117. Sótt af https://onlinelibrary.wiley.com/doi/abs/10.1002/chi.617

Umboðsmaður barna. (2009). Hvernig er að vera barn á Íslandi? Sótt af https://www.barn.is/media/skyrslur/ bok_hvernig_er_ad_vera_barn_a_islandi.pdf

Umboðsmaður barna. (2019). Barnaping 2019. Sótt af https://www.barn.is/barnathing/2019/

Umboðsmaður barna. (2020, 16. apríl). Pátttaka barna í ákvarðanatöku um tilhögun skólastarfs. Sótt af https:// www.barn.is/frettir/thatttaka-barna-i-akvardanatoku-um-tilhogun-skolastarfs

United Nations. (2020, 8. apríl). CRC COVID-19 Statement. Sótt af https://tbinternet.ohchr.org/_layouts/15/ treatybodyexternal/Download.aspx?symbolno=INT/CRC/STA/9095\&Lang=en

Salvör Nordal, Sigurveig Pórhallsdóttir og Eðvald Einar Stefánsson (2020).

Frásagnir barna á tímum COVID-19

Netla - Veftímarit um uppeldi og menntun: Sérrit 2020 - Menntakerfi og heimili á tímum COVID-19

Sótt af http://netla.hi.is/serrit/2020/menntakerfi_heimili_covid19/07.pdf

DOI: https://doi.org/10.24270/serritnetla.2020.14 